\title{
Association of genomewide newborn DNA methylation patterns with maternal and newborn characteristics
}

\author{
Ronald M Adkins ${ }^{1 *}$, Julia Krushkal ${ }^{2}$, Steven Zeisel ${ }^{3}$, Chandrika Piyathilake ${ }^{4}$, Fran Tylavsky², Grant Somes ${ }^{2}$ \\ From UT-ORNL-KBRIN Bioinformatics Summit 2010 \\ Cadiz, KY, USA. 19-21 March 2010
}

\section{Background}

Epigenetics, such as DNA methylation, plays a major role in development and disease risk. Work in model organisms clearly demonstrates that maternal, gestational, genetic and nutritional factors can greatly influence patterns of DNA methylation and increase the risk of disease. In collaboration with a large longitudinal cohort study of human development from gestation to age three, we examined how maternal age, maternal blood nutrient levels and genetic variation are related to neonatal genome-wide DNA methylation patterns.

\section{Materials and methods}

Genome-wide SNP variation was assayed in 96 mothers and their newborns and genome-wide patterns of DNA methylation in 120 newborns. In a subset of 30 mothers, maternal blood levels of several nutrients and metabolites in the one carbon pathway were directly measured. For DNA methylation, the unit of analysis was the average level of methylation across several CpGs within each of $\sim 15,000$ loci. Gene-by-gene, newborn DNA methylation was related to maternal age, maternal blood nutrient levels, and newborn SNP variation.

\section{Results and conclusion}

Genome-wide there is a generally negative correlation between maternal age and newborn methylation in CpG islands. At a subset of loci, particularly the $\mathrm{X}$ chromosome, there was a distinctly bimodal distribution of DNA methylation among newborns that was highly associated with SNP variants on other chromosomes.

\footnotetext{
* Correspondence: radkins1@uthsc.edu

'Department of Pediatrics \& Children's Foundation Research Center of Memphis, University of Tennessee Health Science Center, Memphis TN 38103, USA
}

Among maternal blood nutrients surveyed, phosphatidyl choline showed a significant correlation with newborn DNA methylation at a subset of loci.

Maternal age and blood nutrient levels are correlated with newborn DNA methylation patterns. Trans-acting SNPs are suggestively associated with bimodal patterns of DNA methylation at some loci.

\section{Author details}

${ }^{1}$ Department of Pediatrics \& Children's Foundation Research Center of Memphis, University of Tennessee Health Science Center, Memphis TN 38103, USA. ${ }^{2}$ Department of Preventive Medicine, University of Tennessee Health Science Center, Memphis TN 38163, USA. ${ }^{3}$ Nutrition Research Institute, University of North Carolina, Kannapolis, NC 28081, USA. ${ }^{4}$ Molecular Epidemiology Laboratory, University of Alabama, Birmingham, AL 35294, USA.

Published: 23 July 2010

doi:10.1186/1471-2105-11-S4-O4

Cite this article as: Adkins et al.: Association of genomewide newborn DNA methylation patterns with maternal and newborn characteristics. BMC Bioinformatics 2010 11(Suppl 4):O4.

Submit your next manuscript to BioMed Central and take full advantage of:

- Convenient online submission

- Thorough peer review

- No space constraints or color figure charges

- Immediate publication on acceptance

- Inclusion in PubMed, CAS, Scopus and Google Scholar

- Research which is freely available for redistribution 